\section{Social Change and Primitive Law: Consequences of a Papuan Legal Case*}

LEOPOLD POSPISIL

Yale University

"In the primitive world volitional inventiveness is truly a rare occurrence. Conscious tinkering with the social structure or with gadgetary improvement is not the order of the day. Most primitive inventions are nonvolitional." So reads a statement by E. Adamson Hoebel $(1949: 470)$.

THIS paper presents one of those exceptional volitional inventions by means of which a member of an unpacified primitive Papuan society radically changed the social structure of his village and political confederacy. The history of the legal case and the consequent changes were recorded during research among the Kapauku. Papuans of Netherlands New Guinea in 1954.

The Kapauku live by means of horticulture in the Central Highlands in the area of the large Wissel Lakes. Patrilineal descent, patrilocal residence, and, ideally speaking, the patriarchal polygynous family are the principal characteristics of their social structure. Approximately 15 households form a village inhabited by individuals belonging to the same patrilineage. A confederacy, composed of two or three intermarrying sibs and comprising a total of four to seven villages, unites about 600 people in a strong political group. Beyond this unit, war and diplomatic negotiations prevail; within the group, law and order are administered by wealthy headmen. Every village has its headman, and the most influential of these is elevated to confederacy leadership.

The protagonist of our story is Awiitigaaj, the headman of the village of Botukebo, a prosperous pig breeder, a courageous war leader, and an enthusiast about feminine beauty. Like any connoisseur, he collected some extremely valuable specimens by marrying ten of the most attractive women in the Kamu Valley. Unfortunately, he discovered that the incest taboo-which prohibits marrying an individual of the same sib-would deprive his collection of at least one outstanding example of female pulchritude. Nevertheless, in 1935, he did not hesitate to break the taboo. Although he was the first man in the Kamu Valley to contract such an incestuous marriage, be knew that in the nearby Pona region some Adii men had contracted similar marriages and had succeeded in escaping social sanctions. The bride in question lived in the neighboring village of Kojogeepa and belonged to the same sib, but to another sublineage. To avoid the traditional penalty of execution, he eloped with the girl

* This paper was read in abbreviated form at the Symposium on New Guinea, during the Annual Meeting of the American Anthropological Association, Dec. 27, 1957, at Chicago. The research among the Kapauku Papuans of Netherlands New Guinea, which was conducted in the years 1954-1955, was generously financed by the Ford Foundation. However, the Foundation is not to be understood as approving by virtue of its grant any of the statements made in this article. To the Administration of Netherlands New Guinea I make grateful acknowledgment for support during the period of the research. and hid in the jungle: He assumed that the girl's father would soon realize the futility of pursuit and, after his anger had cooled, might be prepared to accept a payment for his daughter. A bride price, which would ultimately be necessary in any event in order to prevent a rift within the political confederacy, would make the marriage formally valid, and this would absolve Awiitigaaj.

Affairs seemed at first to develop contrary to the plans of our social reformer. The girl's father, the headman of the village of Kojogeepa, ruled that both his daughter and her seducer must be punished by death. His decision was upheld by the headman of the political confederacy. The relatives of Awiitigaaj and of the girl combed the forest for days trying to catch the incestuous couple. After a while, however, the girl's father became tired of the futile search and asked Awiitigaaj's relatives for the bride price, thereby implicitly recognizing the incestuous marriage as rightful. For his financial demand he was able to enlist the support of his own sublineage as well as that of the head of the confederacy. The seducer's relatives, however, refused to pay the price and continued to insist on the capital punishment of the couple. This infuriated the girl's father and, together with his sublineage, he resorted to a stick battle against the seducer's stubborn relatives. Thus, according to customary law, the seducer's relatives were absolved from payment of the bride price by being forced to fight. This release from their obligations induced them to accept and recognize the incestuous union.

Thus, out of expediency, a precedent was established which broke down the traditional incest taboo and which, in the course of time, brought about a farreaching change in the law of the confederacy as well as in its social structure. Following his own precedent, the headman later married two second paternal parallel cousins from his own village. As a headman, he set an example for the other young men of Botukebo. To clothe his actions with an air of legality, he promulgated a new law, proclaiming that it was permissible to marry girls of the same sib and village as long as they were not first paternal parallel cousins. When asked in public about his motives, he gave me the following explanation:

To marry a keneka [girl of the same sib and generation] is good as long as she is a second paternal parallel cousin. In the old days the people did not think of this possibility, but now it is permissible. Adii people [a Kapauku sib living south of the Kamu Valley] have started this change [incest violation] and so I thought we were the same as they and I introduced the new custom. I married my cousins only after I became tonowi [headman] so that other people either were afraid to object or they agreed with me. To marry keneka is not bad, indeed it is nice; in this way one becomes rich.

Since it was obvious that this justification, given in the presence of other people, was a political speech rather than an honest answer, I questioned the headman once again when we were alone, and received the following confidential statement: "Why did I marry my relative? Well, I will tell you, but don't tell the others. I liked her; she was beautiful." To my inquiry about his new incest regulation, he replied with a sly smile and a friendly punch under the ribs: "Please don't tell the others. They wouldn't like me and I would lose influence. As far as I am concerned it would be all right if first cousins were to 
marry. To marry your own sister is probably bad, but I'm not convinced even of that. I think whoever likes any girl should be able to marry her. I set up the new taboo only in order to break down the old restrictions. The people are like that. One has to tell them lies."

By 1954 the new law of incest was accepted by 57.5 percent of the Botukebo adults; 37.5 percent rejected it, and 5 percent were indifferent. The acceptance or rejection of the new rule of course differed in intensity and motivation from individual to individual. Headman Awiitigaaj defended almost complete freedom of choice in obtaining a spouse. Imopaj, who married his third paternal parallel cousin, commented: "All people should be permitted to marry as they wish. However, it is bad to marry one's first paternal parallel cousin. I would beat my younger brother if he tried to commit such an outrage." A man whose sister married her third paternal parallel cousin accepted that marriage, but objected strongly to marriages of relatives closer than the fourth degree of collaterality. Another man of Botukebo objected to any marriage within the same sib: "It is bad. I would never marry my sister. I would beat my son or younger brother if he should try to marry his relative." One older man of Ijaaj sib was even more antagonistic, and proclaimed that he would shoot his son with an arrow if he were to marry a girl from his own sib. Although these informants differed in their opinions on intrasib marriage, they all admitted that their close relatives might commit such an act. A man from another village and sib, who had recently married a Botukebo girl and went to live in her parents' house, was unable even to conceive that his close relative could commit such a crime. In other words, in his mind there was no alternative, not even an illegal one, to the old incest regulation. When asked about the rule of intermarriage in Botukebo he exclaimed with horror: "Bad, bad, a 'sister' is never a spouse. They all are bad. Their vital substance will deteriorate, and they all will die of their crimes."

While 25 years ago there was not a single intrasib marriage in the whole Kamu Valley, by 1954 eleven out of 52 Botukebo marriages had occurred between the members of the same sib. Even the leader of the confederacy, as well as two village headmen and six other men from allied villages, chose their mates from their own sib. Over the last decade, moreover, the pattern of Botukebo marriages shows an increasing tendency toward village endogamy. Out of 14 unions concluded during this period, eight involved partners not only from the same sib but also from the same village. Awiitigaaj's political genius readily seized upon the new trend toward village endogamy. For prestige reasons as well as to withstand the pressure of criticisms, accusations, and threats from outsiders, he decided to render his incest innovation even more appealing by making it more involved and formalistic. He drew an incest line in his own village, dividing it into eastern and western halves to which he assigned proper names. The boundary line was so drawn that all close relatives as far as first cousins had their residence in one of the two units. We may regard these as "incipient moieties." He spoke with favor of marrying into the other unit. A house of one of the villagers which did not fit the headman's scheme even had to be moved to a new location. Moreover, Awitigaaj started to advocate in public speeches a new and revolutionary plan of settlement. $\mathrm{He}$ wanted to change the Botukebo village from an irregular and loose conglomeration of houses into a compact village where the dwellings would stand close together and in one line; one of the new moieties would occupy the southern, the other the northern half of the proposed settlement. Thus the moiety structure would be even more accentuated. These speeches never failed to draw a favorable audience. We may expect that in the near future Botukebo village will be linear, with a main street in front of the houses.

The described changes were not limited to the village, but had repercussions in the political structure of the entire confederacy. The backbone of this political unit is formed by two intermarrying sibs whose members settled in five villages. The marital ties appear to be the mainstay of the political alliance. Since nowadays more and more marriages are concluded within the same sib and even within the same village, the important affinal bond is weakened and esprit de corps vanishes. The trend may finally lead to fragmentation of the political union. Furthermore, the number of intermarriages with other confederacies diminishes. Since at present these affinal relationships provide the main channel for regional understanding, we may expect that with the gradual disappearance of these bonds there will be an increase in hostilities and open wars in the Kamu Valley.

Village endogamy strengthens the status of women. They are no longer strangers marrying into another locality where they must depend entirely on their husbands' affection and judgment. An intravillage marriage provides them with relative independence and a greater influence over their husbands. Emphasis on the male line is lessened, and the situation appears to be favorable to change from patrilineality to bilateral social organization.

It would be interesting to follow these changes in the future and thus test the hypotheses of culture dynamics expressed above. In any event, we have presented the case of an innovator who, by voluntary action and intent, modified his culture as substantially, so to speak, as did Bismarck or Napoleon.

We may wonder if some changes in social conditions might have prepared a favorable ground for acceptance of the new incest rules and the subsequent modifications of the social structure. According to Murdock, "forms of social structure are not determined by kinship patterns or terminology, or influenced in any major degree by them, but are created by forces external to social organization, especially by economic factors" (1949:137). Deriving his assumption from the analysis by Lowie (1920:157-62) of the origin of sibs, as well as from his own research, Murdock postulated that particular techniques of food production, rules of inheritance, and types of residence can strongly influence the forms of social organization. If we inspect the recorded bistory of social change in the village of Botukebo, and if we compare the culture of its residents to that of the other inhabitants of the Kamu Valley or even of those of the neighboring regions, it becomes obvious that none of these specified factors can be regarded as responsible for the acceptance by the society of 
Awiitigaaj's innovations. All over the area food production, division of labor, rules of inheritance, and type of residence are the same. Old informants insisted that no changes occurred in these aspects of culture. Moreover, the outlined sequence of events in Botukebo shows that modification of incest rules and development of "incipient moieties" came first, and that these were followed rather than preceded by changes in the residence patterns.

In several tribes of Netherlands New Guinea, depopulation has been found an important reason for obliteration of exogamy and incest taboos (Bureau for Native Affairs 1957:15, 21). Although certainly important in those situations, this explanation is not applicable to our problem. Rather than diminishing in number, the membership of Awiitigaaj's sib increased significantly during the last hundred years.

Instead, the readiness of the Botukebo people, and of their relatives of the same confederacy, to accept the elimination of sib exogamy can be attributed to certain factors in the sphere of political structure and history. People of the Ijaaj sib of Botukebo are recent immigrants to the South Kamu Valley. Approximately 120 years ago Ijaaj Gepouja, a resident of the Mapia Valley, decided to move into the swampy Kamu Valley and settle in a naturally drained area which in the recent past was covered by a lake. This Papuan pioneer of the Ijaaj sib found plenty of unoccupied fertile land to which he laid claim. He married two women who bore him three sons and several daughters. His sons in turn had 13 male children of their own. Thus the descendants of Ijaaj Gepouja multiplied until they reached the present number of 431 .

Although natural conditions were most favorable to the growing lineage of the Ijaaj sib, the life of its members in the Kamu Valley has not been as easy and agreeable as one would assume. Their territory was surrounded by hostile confederacies of different sibs who looked with envy and hatred upon the prosperous newcomers. These old residents of the adjacent area resented the immigrants' well-being and regarded them as thieves of land which rightfully should have belonged to them. Consequently, the Ijaaj people became involved in numerous wars in which they were invariably outnumbered by the enemy. In order to strengthen their position they formed a confederacy with other newcomers, the people of Pigome sib, whose original home was in the Panial Lake region. In the past, Ijaaj and Pigome people complied with the traditional incest regulations and enforced the sib exogamy. However, on several occasions they found that their wives, brought to their villages from the surrounding hostile political units, were of questionable loyalty. In time of war waged against their own sib-mates, these women betrayed the war plans of their husbands or even deserted them. Moreover, their behavior often became the cause of wars which depleted the resources and decimated the population of the political confederacy. Of 11 wars fought in the past 20 years in the South Kamu Valley, five broke out because of a divorce by a wife from an unfriendly confederacy. These conflicts were inevitable because the male relatives of the divorced women, who regarded the husbands as their own polit-

ical enemies, were unwilling to return the bride price and thus settle the matters peacefully. It is therefore obvious that particular political and historical factors favored endogamy of the discussed sib.

There is another support for our contention that political factors rather than those of economy or residence were responsible for the acceptance of the new incest regulations. When a girl of Ijaaj sib married a member of an enemy confederacy, her male relatives were never sure of receiving the full amount of the bride price. Often their hostile in-laws managed, under the threat of violence, to cheat them of a substantial portion of the agreed sum. Since law an justice are enforced within a political confederacy, such insecurity and eventual economic loss is virtually eliminated in case of intraconfederacy or intrasib marriage. Although in the past the intermarriage of Ijaaj and Pigome people tended to alleviate the precarious political problem of marriages, an Ijaaj man frequently could not find a suitable bride in the other, numerically weak, sib. Consequently, sib endogamy seems to have been the logical answer to the political situation. This conclusion is substantiated even more by the fact that the Pigome people, who found plenty of wives in the numerous Ijaaj sib, maintained firmly the traditional rules of sib exogamy, and successfully resisted the acceptance of Awiitigaaj's innovation.

These social changes in the Papuan confederacy have the following theoretical implications: They testify to the importance of the role an individual may play in the structural transformation of a primitive society; a volitional invention among primitives may not be as exceptional as has been often assumed. The data indicate that political factors should be added to those external forces which Murdock regards as determining the particular forms of social structure. Interestingly enough, in our case residence changed subsequently to social structure rather than being one of the factors contributing to its modification. Finally, exogamy is usually interpreted as contributing to the survival of the group by the elimination of warfare through establishing affinal ties with neighboring people. In our case, the abolition of sib exogamy was socially acceptable just because it appeared to have had the opposite effect.

\section{PFFERENCES CITED}

Bureau for Natrve Afratrs, Holiandia, Netherlands New Gutnea

1957 Anthropological research in Netherlands New Guinea since 1950. A paper presented to the Ninth Pacific Science Congress, Bangkok.

HoEbet, E. ADAMSON

1949 Man in the primitive world. New York, McGraw-Hill Book Company, Inc.

LOWIE, ROBERT H.

1920 Primitive society. New York, Horace Liveright.

MURDOCK, G. P.

1949 Social structure. New York. The Macmillan Company 